\title{
The Influence of Green Location Strategy, Green Price, and Green Promotions toward Purchase Decision of the property
}

\author{
Gatot Sudjatmiko \\ Magister Management \\ Universitas Komputer Indonesia \\ Bandung, Indonesia \\ Gatot.Sudjatmiko@email.unikom.ac.id
}

\author{
Dedi Sulistiyo Soegoto \\ Magister Management \\ Universitas Komputer Indonesia \\ Bandung, Indonesia \\ Dedi.Soegoto@email.unikom.ac.id
}

\begin{abstract}
Green marketing is part of the company's approach to all consumers, with a variety of location-marketing, price, and promotional activities, designed to deliver corporate benefits to minimize the environmental impact of marketed products. Therefore, to increase the benefits for relevant stakeholders an analysis is required in measuring green marketing. This study aims to analyze green location strategy, green price, and green promotions toward the purchase decision either partially or simultaneously. The research method used quantitative method with multiple linear regression analysis Three variables measured were green location strategy, green price, and green promotions as the independent variable, a purchase decision as the dependent variable. The object of this research was the property customer as the unit of analysis. Technique of data collection used saturated random sampling with 100 respondents of property customers in Bandung. The statistical analysis used Classical Assumption Test and hypothesis testing test of $\mathrm{Z}, \mathrm{T}$ and $\mathrm{F}$ with significant level $(\alpha)$ $5 \%$. The result indicated significant influence to the green location strategy, green price, green promotions and purchase decision. Both of variables that were green location strategy, green price, and green promotions toward the purchase decision either partially or simultaneously
\end{abstract}

Keywords :Green Location Strategy, Green Price, Green promotions, and Purchase Decision

\section{INTRODUCTION}

The current era, various consumer product offerings are in the form of a need for a family home that is suitable for habitation. Consumers are very often facilitated with a variety of information circulating widely about the property facilities offered. Consumers are invited to be able to choose properties that are not only useful for fulfilling living conditions and in accordance with applicable eligibility standards, but also the environmentally friendly arrangement process. Based on the phenomenon, this research was conducted to examine how real property companies are trying to build environmentally friendly housing and environmentally friendly property quality that will have implications for customer purchasing decisions; which of course will have a positive impact on the property market in the city of Bandung.

Marketers has responded to consumers' increasing concern for the environment with an approach called green marketing. green marketing generally involves (1) developing product whose production, use, or disposal is less harmful to the environment than the traditional versions of the product; (2) developing products that have a positive impact on the environment; or (3) tying the purchase of a product to an environmental organization or event Error! Reference source not found.. Green marketing is considered as one of the major trends in modern businesses Error! Reference source not found.

\section{a. Green Places}

In the opinion of previous experts that consumers are interested in buying green marketing related places among opinions, by looking at consumption in terms of the consumption space, we can immediately start to locate consumption within an environment. 'Green places' and 'green space' (that is, the physical and psychological experience of a place in terms of its community, ecological conditions and interdependencies) have already begun to receive attention in the ecotourism literature [3]. The location relates to decisions made by the company regarding where operations and staff will be located, the most important of the locations is the type and level of interaction involved in the marketing process. [4]. The more consumers care about environmental degradation, the more importance they place on the environmental consequences of consuming specific products, and the more likely they are to purchase products that are less damaging to the environment [5].

\section{b. Green Price}

In the opinion of previous experts that consumers are interested in purchases related to green marketing on prices between opinions, The consumer purchase intention will also be influenced by other factors like price, branding etc [6]. stated that green marketing and environmental marketing in the late 1980's 
focused on green consumers who would be willing to pay premium prices for more environmentally friendly products. [2]. Functional value is an important factor for customers to decide to purchase products, such as price, performance, purposes, and attributes [7].

\section{c. Green Promotion}

In the opinion of previous experts that consumers are interested in buying green marketing related promotions among opinions, Marketers should emphasize the benefits and values of environmental friendly products through marketing communication. Since products that are environmental friendly are usually more expensive compared to conventional products, perceived risks cannot be avoided in the buying process. However, a message that would encourage risk-taking behavior can be included in their promotional items to counterbalance the negative effect of risk [8]. A majority of people believe that green marketing refers solely to the promotion or advertising of products with environmental characteristics [9]. [10] explained that the promotion strategy included the determination of: (1) the purpose of communication, (2) the role of the components of the promotional mix, (3) the promotion budget, and (4) the strategy of each mix component. The manufacturers may be able to improve the buyers' attitudes through the promotion of green products [15].

\section{d. Green Purchase Decision}

In the opinion of experts previously, consumers were interested in purchasing green marketing among opinions. Consumers may purchase products based on the extent to which they care for the way the consumption of these products affects the natural environment [11]. The green purchase intention may not lead to green purchase behavior [12]. Have developed a model for understanding green purchase intentions among consumers by using four factors - green perceived value, green perceived risk, green trust and green purchase intention and stated that consumers who perceive green products are better for environment will have positive purchase intention towards green products[13]. On the other hand, consumers are also eager to purchase more products that are environmental friendly [14].

\section{METHOD}

Research method used was quantitative method with multiple linear regression analysis. Four variables measured were green location strategy, green price and green promotion as independent variable and purchase decision as dependent variable. The object of this research was property customer as the unit of analysis. Technique of data collection used saturated random sampling with 100 respondents of property customers in Bandung. The statistical analysis used Classical Assumption Test and hypothesis testing test of $\mathrm{Z}, \mathrm{T}$ and $\mathrm{F}$ with significant level $(\alpha) 5 \%$ and calculated by using statistic analysis test.

\section{a. Multiple Linear Regression Green location strategy, Green price and Green promotion to Purchase decision}

By using statistic analysis test, the following results of multiple linear regression analysis are obtained: value a is equal to 0.036 , value of $\mathrm{b} 1$ equal to $0,46, \mathrm{~b} 2$ egual to 0.34 and b3 equal to 0,108 . Thus, the following multiple linear regression equation can be formed:

$$
\mathrm{Y}=0.036+0.46 \mathrm{X} 1+0.34 \mathrm{X} 2+0.108 \mathrm{X} 3
$$

The a and bi values in the above equations can be interpreted as follows:

$\mathrm{c}=0.036$ means: if green location strategy, green price, and green promotion is 0 percent, then purchase decision will be worth $4 \%$ percent.

$\mathrm{x} 1=0.46$ means: if green location strategy increases by one percent while green price and green promotion is constant then purchase decision will increase by $46 \%$ percent.

$\mathrm{x} 2=0,34$ means: if green price increases by one percent while green location strategy and green promotion is constant then purchase decision will increase by $34 \%$ percent.

$\mathrm{x} 3=0,108$ means: if green promotion increases by one percent while green location strategy and green price is constant then purchase decision will increase by $10,8 \%$ percent.

\section{b. Classic Assumption Test}

Furthermore, the analysis of the classical assumption shows as follows:

Best Linier Unbiased Estimation Test :

1. Correlation serial test.

Criteria : $\mathrm{X}^{2}$ statistic $<\mathrm{X}^{2}$ table where 1,376 $<5,99$

Conclusions of acceptance: Model free from serial correlation problem

2. Normality test.

Criteria : Jarque-Bera $<\mathrm{X}^{2}$ table where $2.52<5,99$

Conclusions of acceptance: Residual is normally distributed.

3. Linearity Test

Criteria : F f-statistic $<$ f-table $(0.05 ; 2 ; 100)=3.09$ so that 1.08 $<3.09$

Conclusions of acceptance: Linear model is acceptable

4. Heteroscedasticity Test

Criteria : Obs $*$ R-squared $=1,25<$ table chi-square $(5 \%, \mathrm{df})$ $=5.99$

Conclusions of acceptance: The model passed the heteroscedasticity test

5. Multicoliniarity Test

Criteria : If R-squared $1>\mathrm{R}$-squared 2 then R-squared $1=$ $0.59>\mathrm{R}$-squared $2=0.53>\mathrm{R}$-squared $3=0.55$

Conclusions of acceptance: The model did not find any multicoleniarity

\section{RESULTS AND DISCUSSION}

a. Implications Green location strategy, Green price and Green promotion to Purchase decision

The coefficient of determination (KD) is the square of the correlation coefficient (R) or also known as R-Square. The coefficient of determination serves to find out how much implications Green location strategy, Green price and Green promotion to Purchase decision. 
From the output of statistic analysis test, it is known that the coefficient of determination or $\mathrm{R}$ square is 0,7175 or $71,75 \%$. This shows that Green location strategy and Green price simultaneously give implications to Purchase decision variable equal to $71,75 \%$, So Green location strategy, Green price and Green promotion give big implications to increase Purchase decision because green price which is well managed and increase the green location strategy is expected to improve implications to Purchase decision. While the rest of $28.25 \%$ is the influence of other variables that are not examined outside the Green location strategy, Green price and Green promotion.

\section{b. Correlation Green location strategy, Green price and Green promotion}

To test whether Green location strategy, Green price and Green promotion variables have positive or negative correlation, then statistic testing of $\mathrm{z}$. $\mathrm{H} 0: \beta 1=\beta 2=0$, That is, there is no positive relationship between Green location strategy, Green price and Green promotion in Property in Bandung. $\mathrm{H} 1: \beta \mathrm{i} \neq 0$, That is, there is a positive relationship between Green location strategy, Green price and Green promotion in Property in Bandung.

The level of significance $(\alpha): 0.05$

Test criteria:

- reject H0 if value Z-statistics > Z-table,

- accept Ha if the value of Z-statistics < Z-table From the calculation results obtained $Z$ value of 10.9 . This value will be compared to the $Z$ value of the table. With $\alpha=0.05, Z$ table $=Z \alpha / 2=Z 0,025=1.82$. From the above values, it is known that the value of $Z$-statistics $(17,34)>\mathrm{Z}$ table $(1,82)$, so $\mathrm{H} 0$ is rejected and $\mathrm{Ha}$ accepted, $\mathrm{Z}$ value is positive sign showing relationship between Green location strategy, Green price and Green promotion is the same direction, Green location strategy includes how big Green price is there. Value 14,28 shows that assuming variable X1 (Green location strategy) constant mean there is positive relation between Green location strategy (X1), Green price (X2) and Green promotion (X3) in Property Bandung.

\section{c. Implications of Green location strategy, Green price and Green promotion to Purchase decision either partially. \\ Testing implications Green location strategy (X1) to Purchase decision (Y) either Partial}

Ho: $\beta 1=0$, meaning that Green location strategy partially has no significant implications effect on Purchase decision. Ha: $\beta 1 \neq 0$, It means Green location strategy partially significant implications effect on Purchase decision. With significance level $\alpha=5 \%$

Based on the processing using statistic analysis test, it can be seen that t-Stat value for Green location strategy is 1.66. This value will be compared to the value of table in the distribution table t. With $\alpha=0.05$, $\mathrm{df}=\mathrm{n}-\mathrm{k}-1=96-(3-1)=94$, for the twosided test the value of $\mathrm{t}$ table is 1.66. It is known that $\mathrm{t}$-Stat for $\mathrm{X} 1$ (3.96)> t-table, then Ho accepted means Green location strategy partially significant implications effect on Purchase decision. That is, if Green location strategy is improved, it will have a significant implications effect on improving Purchase decision.

Testing implications Green price (X2) Against Purchase decision $(\mathbf{Y})$

Ho: $\beta 1=0$, Meaning Green price partially no significant implications effect on Purchase decision. Ha: $\beta 1 \neq 0$, Meaning Green price partially significant implications effect to Purchase decision. With significance level $\alpha=5 \%$ Criteria:

- Reject Ho if $t$-Stat is bigger than t-table

- Accept in other things

Based on the results of processing, it can be seen that t-Stat value for Green price is 1.66. This value will be compared to the value of t-table in the distribution table $\mathrm{t}$. With $\alpha=0.05, \mathrm{df}=\mathrm{n}$ $\mathrm{k}-1=96-(3-1)=94$, for the two-sided test the value of table is 1.66. It is known that t-Stat for X2 (3.04)> t-table, then Ho accepted means Green price partially significant implications effect to Purchase decision. That is, if Green price is improved, then implications effect to Purchase decision will increase in Property in Bandung.

Testing implications Green promotion (X3) Against Purchase decision (Y)

Ho: $\beta 1=0$, Meaning Green promotion partially no significant implications effect on Purchase decision. Ha: $\beta 1 \neq 0$, Meaning Green promotion partially significant implications effect to Purchase decision. With significance level $\alpha=5 \%$ Criteria:

- Reject Ho if t-Stat is bigger than t-table - Accept in other things

Based on the results of processing, it can be seen that t-Stat value for Green promotion is 1.66. This value will be compared to the value of $\mathrm{t}$-table in the distribution table $\mathrm{t}$. With $\alpha=0.05$, df $=\mathrm{n}-\mathrm{k}-1=96-(3-1)=94$, for the two-sided test the value of $\mathrm{t}$ table is 1.66. It is known that t-Stat for X2 (1.76)> t-table, then Ho accepted means Green promotion partially significant implications effect to Purchase decision. That is, if Green promotion is improved, then implications effect to Purchase decision will increase in Property in Bandung.

c. Implications Effect of Simultaneous Implications Green location strategy and Green price against Purchase decision.

To test whether Green location strategy, Green price and Green promotion variables simultaneously give significant implications to Purchase decision, then the simultaneous hypothesis testing is as follows: $\mathrm{H} 0: \beta 1=\beta 2=0$, That is, there is no implications Green location strategy, Green price and Green promotion at Property in Bandung.

Ha: $\beta \mathbf{i} \neq 0$, That is, there is implications Green location strategy, Green price and Green promotion at Property in Bandung.

The level of significance $(\alpha): 0.05$

Test criteria: 
- reject $\mathrm{HO}$ if value $\mathrm{F}$-stat $>\mathrm{F}$-table,

- accept Ha if the value of F-stat $<$ F-table

From the data processing with using statistic analisys test, we can know the value of F-stat equal to 33,06 . This value will be compared to the $\mathrm{F}$ table value. With $\alpha=0,05, \mathrm{v}=2$ and $\mathrm{df}=$ 94, it is known that $\mathrm{F}$ table value is 3.09. From the above values, it is known that F-stat $(47,30)>\mathrm{F}$ table $(3.09)$, so H0 is accepted and $\mathrm{Ha}$ is rejected, meaning there is significant simultaneous implications of Green location strategy (X1), Green price (X2) and Green promotion (X3) to Purchase decision (variable Y), indicating that implications Green location strategy, Green price and Green promotion simultaneously have a significant effect on Purchase decision. The result of the research indicated that implications Green location strategy, Green price and Green promotion simultaneously give implications to Purchase decision variable equal to $59,6 \%$, this means that if Green location strategy, Green price and Green promotion are properly managed and enhanced, their implications to Purchase decision will increase as well. The result showed in the research is in line with the prior research that implications purchase decision is influenced by the good green marketing of Green location strategy, Green price and Green promotion.

\section{CONCLUSIONS}

Based on the results of data analysis and discussion that has been done, the authors take the following conclusions: There is a positive relationship between Green location strategy, Green price and Green promotion, at property Bandung. Application of Green location strategy good able to increase purchase decision, and good Green price, Green promotion able to increase their implications to purchase decision. Green location strategy partially significant implications effect on Purchase decision. This may be due to the fact that in property, and Green location strategy influences partially implications to purchase decision, so also reel green property excellence. Green price and green promotion partially significant implications effect to Purchase decision. That is, if Green price and green promotion is improved, then implications effect to Purchase decision will increase at Property in Bandung. Customers who receive the benefits will feel good they are against company and green property.The research indicated there is significant simultaneous implications of Green location strategy, green price and green promotion to Purchase decision, and indicating that implications Green location strategy, green price and green promotion simultaneously have a significant effect on Purchase decision. this means that if Green location strategy, green price and green promotion are properly managed and enhanced, their implications to Purchase decision will increase as well.

\section{REFERENCES}

[1] Hawkins, Del I and Mothersbaugh David L. Consumer Behaviour : Building Marketing Strategy. 12th ed. New York :McGraw-Hill. 89 (2013)

[2] Ishaswini and Saroj Kumar Datta. 'Pro-environmental Concern Influencing Green Buying: A Study on Indian Consumers', International Journal of Business and Management Vol. 6, No. 6; (2011)

[3] Walker, R. and Hanson, D. 'Green Marketing and Green Places: A Taxonomy for the Destination Marketer', Journal of Marketing Management, vol. 14 (6), pp. 623-640 (1998)

[4] Soegoto Sulistiyo, Dedi. Pengaruh Kinerja Bauran Pemasaran Jasa Keunggulan Positions Terhadap Kepuasan Penumpang Dan Implikasinya Pada Kepercayaan Penumpang Pesawat Perusahaan Penerbangan Rute Jakarta-Surabaya. Majalah Ilmiah Unikom, Vol.8 No.1 (2011).

[5] Kilbourne, W., \& Pickett, G. How materialism affects environmental beliefs, concern, and environmentally responsible behaviour. Journal of Business Research, 61, 885-893 (2008).

[6] P. K. Kumar and B. Anand, "A Study on Consumer Behavior towards EcoFriendly Paper," vol. 13, no. 11, 2013.

[7] Tsai-Feng Kao and Yi-Chan Tu. 'Effect of Green Consumption Values On Behavior: The Influence Of Consumption Attitude', International Journal of Arts \& Sciences, 08(08):119-130 (2015)

[8] M. J. Kwok and M. M. Lau, "Examining How Environmental Concern Affects Purchase Intention: Mediating Role of Perceived Trust and Moderating Role of Perceived Risk,” vol. 11, no. 2, pp. 143-152, 2015.

[9] P. G. S. H, B. Com, M. Phil, B. Ll, and P. D. Pursuing, "A Study of Evolution and Practice of Green Marketing by Various Companies in India," vol. 2, no. 7, 2013.

[10] Cravens, David W., and Nigel F. Piercy. Strategic Marketing. New York: Mc Graw Hill, 402 (2003)

[11] Follows, S. B., and Jobber, D. Environmentally responsible purchase behaviour: A test of consumer model. European Journal of Marketing, 34(5/6), 723-746 (2000).

[12] Akehurst, G., Afonso, C., and Goncalves, H. M. Re-examining green purchase behavior and the green consumer profile: new evidences. Management Decision 50 (5), 972-988 (2012)

[13] Chen, Y.S. and Chang, C.H. Enhance green purchase intentions: The roles of green perceived value, green perceived risk, and green trust. Management Decision, 50(3), 502-520 (2012). http://dx.doi.org/10.1108/00251741211216250.

[14] Kalafatis, S.P. \& Pollard, M. Green marketing and Ajzen's theory of planned behavior: A cross-market examination. Journal of Consumer Marketing, 16(5), 441-460 (1999). http://dx.doi.org/10.1108/07363769910289550. 